\title{
Sosialisasi Pemilu Tahun 2019 terhadap Pemilih Pemula oleh KPU Kabupaten Solok Selatan
}

\section{Cici Riska Aprilia, Alia Azmi}

Prodi Pendidikan Pancasila dan Kewarganegaraan

FIS Universitas Negeri Padang

E-mail: azmialia@gmail.com

\section{ABSTRAK}

Artikel ini mengungkapkan bagaimana upaya Komisi Pemilihan Umum (KPU) Kabupaten Solok Selatan dalam pelaksanaan sosialisasi Pemilu bagi pemilih pemula tahun 2019. Selain itu, artikel ini juga menjelaskan kendala yang ditemui oleh KPU dalam pelaksanaan sosialisasi Pemilu. Penelitian ini menggunakan pendekatan kualitatif dengan bentuk studi deskriptif. Informan dari artikel berjumlah 12 orang yang mencakup staff ahli di KPU Solok Selatan, guru, mahasiswa, siswa, dan pihak radio. Jenis data terdiri dari data primer dan sekunder yang dikumpulkan melalui wawancara, observasi dan dokumentasi. Teknik analisis data dilakukan melalui reduksi data, penyajian data, interprestasi data dan pengambilan kesimpulan. Hasil penelitian menunjukkan upaya yang dilakukan KPU dalam melaksanakan sosialisasi pemilu adalah dnegan melakukan kunjungan ke sekolah, kampus, dan radio setempat.

Kata Kunci: sosialisasi Pemilu, KPU, pemilih pemula, Solok Selatan

\section{ABSTRACT}

This article describe how the General Election Commission (KPU) of South Solok Regency in the implementation of Election socialization for first-time voters in 2019. In addition, this article also describes the obstacles encountered by the KPU in implementing election socialization. This research uses a qualitative approach with a descriptive study. The informants of the article are 12 people including expert staff at the KPU of South Solok , teachers, students and the radio. Types of data consist of primary and secondary collected through interviews, observation and documentation. Data analysis techniques done by reduction, presentation, interpretation and conclusion. The results showed that the efforts made by the KPU in implementing election socialization were by visiting schools, campuses and local radio.

Keywords: election socialization, KPU, beginners voters, District of Solok Selatan

(c) (1) (9) This work is licensed under the Creative Commons Attribution-ShareAlike 4.0 International License. (C)2020 by author. 


\section{PENDAHULUAN}

Rakyat merupakan pusat dari segala bentuk aktifitas politik negara. Perkembangan pelaksanaan demokrasi dari sebuah negara ditandai dengan seberapa jauh rakyatnya memberikan aspirasi politik. Masyarakat diharapkan menjadi pelopor dalam kebijakan negara sekaligus pemeran utama yang bertugas mengutamakan kepentingan publik. Adapun wujud nyata dalam demokrasi di Indonesia adalah dilaksanakannya pemilu. Partisipasi rakyat dalam pelaksanaan pemilu merupakan hal yang mutlak. Berhasil atau tidaknya pemilu tergantung dari bagaimana rakyat memberikan hak suaranya.

Memilih sosok pemimpin kepala daerah merupakan sebuah momen yang sangat penting. Dalam hal ini masyarakat tidak hanya dituntut menggunakan hak pilihnya, tetapi yang terpenting adalah bagaimana mereka memberikan yang terbaik untuk bangsa dan negaranya. Di Indonesia sendiri remaja adalah sebuah komunitas yang cukup besar yang patut diperhitungkan suaranya dalam pemilu. Remaja ini sering juga disebut dengan pemilih pemula. Pemilih pemula sendiri merupakan mereka yang baru pertama kali menggunakan hak pilihnya, berkisar umur 17-22 tahun yang terdiri dari siswa dan atau mahasiswa.

Sosialisasi pemilu terhadap pemilih pemula sangat penting dilakukan karena terdapat transfer pengetahuan politik yang berkaitan dengan hak, sistem, tahapan serta lembaga penyelenggara pemilu. Untuk itu dalam pelaksanaan sosialisasi pemilu perlulah berkaitan dengan kompetensi kewarganegaraan yang utuh. Kompetensi kewarganegaraan adalah seperangkat pengetahuan, nilai, sikap serta keterampilan yang mendukung menjadi warga Negara yang partisipatif dan bertanggung jawab dalam kehidupan bermasyarakat dan bernegara (Branson, 1999). Tiga kompetensi kewarganegaraan yang harus dimiliki oleh pemilih pemula adalah:

pengetahuan kewarganegaraan, kecakapan dan watak kewarganegaraan yang mengisyaratkan pada karakter publik yang penting bagi pemeliharaan dan pengembangan demokrasi konstitusional (Branson, 1999).

Sosialisasi pemilu sebagai proses dalam pembentukan dan pengembangan kompetensi kewarganegaraan saat ini merupakan kebutuhan dasar dari pemilih pemula. Hal ini sangat penting mengingat bagaimana calon pemimpin yang akan dipilih. Mereka dituntut untuk membangun kesadaran dan daya kritis terhadap tahapan pelaksanaan pemilu. Mereka tidak hanya sebagai objek pemilu tetapi juga sebagai pendorong pendewasaan partai politik yang memperjuangkan aspirasi rakyat sehingga mampu menumbuhkan demokrasi di Indonesia.

Rendahnya partisipasi politik pemilih pemula disebabkan salah satu faktornya adalah sosialisasi yang hanya dilakukan menjelang pemilu. Belum optimalnya program kerja Komisi Pemilihan Umum (KPU) dalam memberikan pemahaman dan kesadaran bagi pemilih pemula untuk ikut berpartisipasi dalam pemilu mengakibatkan rendahnya partisipasi mereka. Peran KPU seharusnya 
adalah menanamkan kesadaran dalam melaksanakan Pemilu sehingga bisa memberikan pedoman terhadap penetapan organisasi dan tata cara penyelenggaraan sesuai dengan tahapan yang diatur dalam undangundang.

Sosialisasi pemilu dilakukan ke berbagai kelompok target seperti penyandang disabilitas. Mereka juga adalah kelompok masyarakat yang harus dipertimbangkan partsisipasinya dalam kehidupan bernegara. Pelaksanaan sosialisasi dilakukan kepada penyandang disabilitas dengan harapan mereka dapat menjadi agen-agen yang tidak terjangkau oleh KPU (Rita, 2016). Di wilayah lainnya di Sumatera Barat seperti Kabupaten Sijunjung sosialisasi dinilai sudah maksimal. KPU Kabupaten Sijunjung mendatangi beberapa kampus, sekolah, maupun kelompok masyarakat tertentu dalam kegiatan sosialisasinya (Triralmaidi, 2019). di Provinsi lainnya juga sudah dilaksanakan sosialisasi terhadap pemilih pemula dan dinilai efektif (Novianti, 2018). Proses sosialisasi yang dilakukan KPU, tidak hanya mengajak masyarakat untuk datang ke Tempat Pemungutan Suara (TPS) tetapi juga mengajak masyarakat untuk menjaga ketertiban dan kelancaran pemilu (Djuyandi, 2014).

Berangkat dari uraian diatas, maka penulis tertarik untuk melakukan penelitian yang lebih mendalam tentang sosialisasi pemilu 2019 terhadap pemilih pemula oleh KPU Kabupaten Solok Selatan. Artikel ini berusaha menjawab pertanyaan: pertama, bagaimanakah bentuk sosialisasi pemilu; kedua, bagaimanakah metode sosialisasi kepada pemilih pemula; ketiga, apa kendala yang ditemui oleh KPU dalam pelaksanaan sosialisasi pemilu tahun 2019 di Kabupaten Solok Selatan.

\section{METODE PENELITIAN}

Metode penelitian yang digunakan adalah kualitatif deskriptif yang berusaha mendeskripsikan fenomena dari peristiwa yang terjadi. Narasumber penelitian ini adalah Ketua dan anggota KPU, guru, siswa, mahasiswa serta pihak radio. Teknik pengumpulan data yang digunakan dalam penelitian ini adalah teknik observasi dan dikomunikasikan langsung dengan narasumber. Teknik studi dokumenter juga digunakan dalam penelitian ini dengan alat pengumpul datanya adalah pedoman observasi dan wawancara. Untuk teknik analisis data dilakukan pada tahap pengumpulan data, reduksi data dan verifikasi data.

\section{HASIL DAN PEMBAHASAN}

KPU merupakan lembaga penunjang negara yang bertugas untuk menyelenggarakan pemilihan umum. Dalam menyelenggarakan pemilu KPU memiliki tugas melakukan sosialisasi politik. Sosialisasi ini kemudian dilaksanakan tidak hanya dalam hal tahap-tahap pemilu serta sosialisasi calon-calon peserta pemilu, namun juga sosialisasi yang berbentuk pendidikan politik. Di Indonesia, peraturan tentang sosialisasi pemilu terdapat dalam Pasal 25 ayat 1 Peraturan Komisi Pemilu RI No. 10 Tahun 2018. Dalam undang-undang ini dijelaskan tentang penyebarluasan informasi tahapan, jadwal dan program Pemilu sehingga dapat meningkatkan partisipasi Pemilih. 
Sosialisasi merupakan sebuah proses dalam merubah pemikiran individu atau kelompok agar ia mampu untuk berperan dan menyesuaikan dirinya untuk memiliki fungsi yang sama dalam kelompok. Sosialisasi adalah sebuah interaksi sosial yang diberikan kepada masyarkat untuk pemberian pengetahuan, pembentukan nilai dan sikap, serta perilaku agar dapat berpartisipasi aktif dalam kelompok masyarakat secara efektif (Putra, 2016). Sosialisasi politik ialah sebuah proses pembentukan sikap dan orientasi para anggota masyarakat dimana kemudian mereka memperoleh sikap dan orientasi terhadap kehidupan (Surbakti, 2010). Proses yang dilakukan berlangsung selamanya dengan cara yang baik dan terarah melalui pendidikan politik baik secara formal maupun informal dalam kehidupan sehari-hari.

KPU Kabupaten Solok Selatan selaku penyelenggara pemilu memiliki tugas dan fungsi tambahan untuk mendukung penyelenggaraan pemilu yang berkualitas di tingkat daerah. Fungsi dan tugas tersebut termaktub dalam UU No. 15 Tahun 2011 tentang Penyelenggaran Pemilu. Fungsi sosialisasi dilakukan dalam bentuk pendidikan politik dalam tiga bentuk; KPU go to school, KPU go to kampus, dan Talkshow radio.

Dalam program KPU Go To School, sosialisasi ini dilakukan KPU bagi pemilih pemula dan guru-guru yang ada disana. Siswa-siswa kelas $X$ dan XI SMA/SMK/MA sederajat di kabupaten Solok Selatan diberikan sosialisasi tentang berbagai hal terkait pemilu. Program KPU ini juga menjadi bahan ajar bagi guru PKn sebagai suatu pendidikan demokrasi.
Program ini juga diharapkan dapat mewujudkan upaya pendidikan yang berkesinambungan dan tidak instan. Harapannya adalah terbentuknya pemilih pemula yang berkualitas dan siap berperan aktif dalam agenda demokrasi (Wawancara dengan Nila Puspita, Ketua KPU Kabupaten Solok Selatan).

Pada tahun 2019 ini materi yang disampaikan hampir sama dengan tahun-tahun sebelumnya. Sosialisasi menyangkut: pentingnya turut berpartisipasi dalam pemilu, karakteristik calon kepala daerah yang baik dan bagaimana KPU menyusun daftar pemilih. Dalam sosialisasi ini juga dilakukan simulasi pemungutan suara (wawancara dengan Andi Andrawan Putra, divisi social pendidikan pemilih partisipasi, masyarakat dan ESDM).

Dalam kegiatan KPU Go to School dilakukan melalui metode role playing dan simulasi. Role playing atau permainan peran adalah metode pembelajaran yang diarahkan untuk mengkreasi peristiwa-peritiwa actual (Abza, 2019). Selain itu juga dilakukan dengan metode simulasi. Simulasi adalah situasi buatan yang menyerupai kondisi dan situasi yang sesungguhnya atau melakukan latihan nyata tanpa harus menghadapi resiko yang sebenarnya (Abza, 2019). Simulasi dilengkapi dengan petunjuk tentang cara penggunaan berupa bahan penyerta. Metode role playing dan simulasi dianggap metode yang sangat tepat digunakan untuk pemilih pemula dari kalangan siswa. Para siswa dapat terlibat lansung dalam kegiatan ini, ada yang terlibat sebagai pemilih, petugas KPPS dan lain sebagainya. 
KPU Go to School merupakan agenda tahunan yang dilakukan oleh KPU Kabupaten Solok Selatan sesuai dengan UU No. 15 Tahun 2011 tentang pelaksanaan sosialisasi. Program ini dilakukan ke 17 sekolah yang ada di Solok Selatan. Diperkirakan pada pemilu tahun 2019 terdapat 7.360 pemilih pemula yang antusias dalam mengikuti pemilu tersebut.

Selain ke sekolah, KPU Kabupaten Solok Selatan juga melaksanakan program sosialisasi ke kampus atau yang dikenal dengan KPU Go to Kampus. Hampir sama dengan KPU Go to School, program ini bertujuan memberi pemahaman tentang aspekaspek demokrasi dan pemilu kepada pemilih pemula di tingkat kampus. Namun yang membedakan adalah materi sosialisasi yang disampaikan, yaitu: Pancasila, UUD 1945, Pendidikan Kewarganegaraan (PKn), dan pemilihan umum di Indonesia.

Metode yang digunakan pada KPU Go to Campus adalah generalisasi. Generalisasi merupakan sebuah proses penalaran yang membentuk kesimpulan umum melalui suatu kejadian, hal atau persitiwa. Metode ini mengembangkan bagaimana seseorang dapat memahami apa yang telah disampaikan oleh orang lain dan menyerapnya dengan baik. Metode ini memiliki beberapa tahapan yaitu analisis, desain, pengujian dan pemeliharaan (Aryandana, 2016). Metode ini cocok diberikan kepada mahasiswa karena mereka sudah mendapatkan kegiatan sosialasi sebelumnya semasa sekolah. Sehingga KPU hanya memberikan sosialisasi singkat agar mereka dapat mengingat dan menyimpulkan kembali bagaimana tata cara memilih yang baik dan benar.

Untuk mempopulerkan pemilu di tingkat pemilih pemula, KPU juga melakukan talkshow lewat radio lokal. Pelaksanaan sosialisasi lewat radio dilaksanakan 16 kali penayangan dalam sehari dengan materi yang hampir sama dengan KPU go to school dan KPU go to Campus. Namun hal yang berbeda dengan talk show di radio adalah, kegiatan ini juga menjangkau para guru. Guru diharapkan dapat berperan sebagai agen sosialisasi bagi anak didiknya melalui proses kegiatan belajar mengajar di sekolah.

Dalam pelaksanaan sosialisasi bagi pemilih pemula ini, KPU juga menghadapi berbagai kendala. Kendala merupakan hambatan yang menghalangi pencapaian suatu tujuan. Secara umum, terdapat dua faktor yang menyebabkan terjadinya kendala dalam pemilu (Arianto, 2011), yaitu: internal dan eksternal. Factor internal merupakan faktor yang berasal dari dalam sebuah organisasi atau lembaga itu sendiri. Sedangkan faktor eksternal merupakan kendala yang berasal dari luar, seperti lingkungan sosial, masyarakat dan lain sebagainya.

Berdasarkan wawancara dnegan ketua KPU Kabupaten Solok Selatan, setidaknya terdapat empat kendala utama yang dihadapi oleh KPU Kabupaten Solok Selatan dalam melaksanakan sosialisasi pemilu. Pertama, terbatasnya jumlah sumber daya manusia. Berdasarkan hasil observasi yang peneliti lakukan, jumlah pendamping sosialisasi yang terjun langsung ke lapangan hanya 10 sampai 15 orang. Semuanya dibagi menjadi beberapa kelompok yang 
bertugas dalam menyampaikan sosialisasi pemilu ke sekolah. Kedua, wilayah target sosialisasi cukup jauh.

Kabupaten Solok Selatan merupakan wilayah pegunungan sehingga ada beberapa lokasi yang sulit ditempuh melalui jalur darat. Hal ini berdampak kepada penyampaian sosialisasi di daerah yang hanya dapat dijangkau oleh anggota KPU. Ketiga, kondisi alam, cuaca yang tidak mendukung serta sarana dan prasarana tidak memadai selalu menghambat tujuan sosialisasi. Keempat, minimnya sarana dan prasarana pendukung sosialisasi. KPU Kabupaten Solok Selatan pada saat ini hanya mempunyai satu buah mobil dinas. Mobil tersebut digunakan oleh semua anggotanya. Tidak jarang mobil tersebut harus mengantar pendamping sosialisasi ke tempat tujuan yang berbeda dalam satu waktu. Sehingga banyak waktu yang terbuang percuma di jalan.

\section{KESIMPULAN}

Jumlah pemilih pemula yang cukup banyak di Kabupaten Solok Selatan yaitu 7.320 orang atau sekitar $20 \%$ dari jumlah penduduk keseluruhan menjadikan mereka sebagai kelompok target sosialisasi oleh KPU. Mereka perlu diarahkan agar menjadi pemilih yang cerdas dan dibentuk pola pikirnya sehingga tidak terpengaruh oleh politik uang (money politic) dan kampanye hitam. KPU Kabupaten Solok Selatan sudah melaksanakan program sosialisasi pemilu bagi pemilih pemula melalui tiga program yaitu, KPU go to School; KPU go to Kampus; dan Talkshow radio. Dalam pelaksanaan program, KPU menyampaikan melalui metode role playing, simulasi dan generalisasi diimana masing-masing metode tersebut bekerja sesuai dengan target yang dipilih. Sementara itu, terdapat beberapa kendala dalam pelaksanaan sosialisasi pemilu, antara lain: jumlah sumber daya manusia yang terbatas, wilayah target sosialisasi yang jauh, factor cuaca atau alam dan minimnya sarana pendukung kegiatan sosialisasi.

Dalam menghadapi kendala tersebut, KPU Kabupaten Solok Selatan sebaiknya melakukan koordinasi dengan Musyawarah Guru Mata Pelajaran (MGMP) PKn di Kabupaten tersebut. Hal ini dilakukan agar ada pembagian peran yang konstruktif antara pembelajaran politik di sekolah dengan sosialisasi politik oleh KPU. Program-program sosialisasi pemilu oleh KPU juga sebaiknya dibuat lebih beragam, seperti program workshop, olimpiade pemilu, dan lain sebagainya. Program ini seharusnya dapat dijalankan secara rutin dan dalam pelaksanaanya dapat menarik minat pemilih pemula.

\section{DAFTAR PUSTAKA}

Arianto, B. (2011). Analisis penyebab masyarakat tidak memilih dalam pemilu. Jurnal Ilmu Politik dan Ilmu Pemerintahan, 1(1), 51-60.

Abza, A. T. P. (2019). Simulasi Animasi Dua Dimensi Untuk Pemilih Pemula Dalam Informasi Tata Cara Pemilihan Umum Kepala Daerah Dengan Metode LutherSutopo. Jurnal Intra Tech,3(1), 28-37.

Branson, M.S. (1999). Making the Case for Civic Education: Where We Stand at the End of the 20 th Century. Calabasas: Center for Civic Education. 
Dedi Triralmaidi. 2019. Sosialisasi KPU Kabupaten Sijunjung Dalam Upaya Meningkatkan Partisipasi Pemilih Dalam Pilkada Tahun 2015. Nusantara: Jurnal Ilmu Pengetahuan Sosial Vol. 6 Nomor 2 Tahun 2019 Hal:282297 ISSN Online: 2550-0813.

Fety Novianty. 2018. Peran Komisi Pemilihan Umum (KPU) Dalam Menumbuhkan Partisipasi Politik Bagi Pemilih Pemula Di Kecamatan Pontianak Barat. Sosial Horizon: Jurnal Pendidikan Sosial Vol. 5, No. 2, Desember 2018 ISSN 24075299.

I Gede Sugita Aryandana, Dkk. 2016. Pembentukan Data Mart Menggunakan Metode Generalization. Lontar Komputer Vol.7, No.3, Desember 2016 pISSN 2088-1541.

Rita, M. IArianto, B. (2011). Analisa, Y. 20Pengetahuan Sosial VJ dalam sosialisasi pemilukada kepada penyandang disabilitas di kota Bandar lampung. Jurnal Kultur Demokrasi, 5(1).

Putra, Arry Dharmawan Trissatya. 2016. "Inovasi Model Sosialisasi Peran Serta Masyarakat Dalam Pemilu". Jurnal Wacana Politik. Vol. 2 (1). (hlm. 139-151).

Ramlan, S. (2010). Memahami Politik. Jakarta: Gramedia Widia sarana Indonesia. Yusa Djuyandi. 2014. Efektivitas Sosialisasi Politik Pemilihan Umum Legislatif Tahun 2014 Oleh Komisi Pemilihan Umum. HUM ANIOR A Vol.5 No.2 Oktober 2014: $\quad$ 1202-1212.

Undang-undang No. 22 Tahun 2007 Tentang Penyelenggaraan Pemilihan Umum 